\title{
ISOLASI, IDENTIFIKASI KOMPONEN DAN UJI AKTIVITAS ANTIBAKTERI MINYAK ATSIRI RIMPANG LEMPUYANG WANGI (Zingiber aromaticum Val.)
}

\author{
Nestri Handayani*, Widyo Wartono, Nirub Wijaya \\ Jurusan Kimia FMIPA Universitas Sebelas Maret Surakarta \\ Jl. Ir. Sutami 36 A Surakarta 57126 \\ Email : nestrihandayani@yahoo.com
}

\begin{abstract}
ABSTRAK
Isolasi, identifikasi dan uji aktivitas antibakteri minyak atsiri rimpang lempuyang wangi (Zingiber aromaticum Val.) telah dilakukan. Minyak atsiri diisolasi dengan metode destilasi Stahl dan dianalisis dengan GC-MS. Kadar minyak atsiri yang dihasilkan 0,6\% (v/b). Identifikasi komponen dilakukan dengan membandingkan spektrum massa masingmasing senyawa dengan spektrum massa senyawa standar dari literatur Wiley 7. LIB. Hasil analisis menunjukkan 27 senyawa teridentifikasi yaitu $\alpha$ - pinen $(0.36 \%), \mathrm{Z}-\beta$ ocimen (2.70\%), Champhen (10.91\%), Sabinen (0.07\%), $\beta$ - pinen $(0.18 \%), \beta$ - myrcen $(0.29 \%),(\mathrm{Z})$ - $\alpha$-osimen $(0.51) \%$, allo-osimen $(0.08) \%, \mathrm{p}-$ cimen $(0.50 \%), 1,8$ cineol (2.75\%), $\beta$ - trans ocimen $(0.05 \%), \gamma-$ terpinen $(0.14 \%), \alpha$ - terpinolen $(27.19 \%)$, champor $(2.71 \%)$, Isobornyl alcohol (1.51\%), Terpinen 4-ol (1.11\%), 3-cycloheksan 1 metanol $(0.25 \%)$, Isobornyl acetat $(0.29 \%)$, Trans caryophilen $(0.47 \%)$, $\alpha$-humulen (7.53\%), $\alpha$-kurkumen $(0.13) \%$, farnesol $(0.11 \%),(-)$-kariofilen oksida $(2.07 \%)$, patchulana $(0.25 \%)$, Zerumbon $(31.05 \%)$.

Uji aktivitas antibakteri minyak atsiri rimpang lempuyang wangi (Zingiber aromaticum Val.) telah dilakukan terhadap Pseudomonas aeruginosa dan Salmonella typhi dengan metode difusi agar menggunakan metode difusi dengan membuat sumuran. Hasil uji antibakteri menunjukkan bahwa minyak atsiri rimpang lempuyang wangi (Zingiber aromaticum Val) memiliki aktivitas antibakteri terhadap semua bakteri uji dengan Konsentrasi Hambat Minimum (KHM) 0,25\% untuk Pseudomonas aeruginosa, dan 0,075\% untuk Salmonella typhi. Dibandingkan dengan amoksisilin, potensi antibakteri minyak atsiri rimpang lempuyang wangi (Zingiber aromaticum Val) pada kedua bakteri uji adalah $0,001 \%$ dari potensi amoksisilin.
\end{abstract}

Kata kunci : Zingiber aromaticum Val., minyak atsiri, antibakteri

\section{ISOLATION, IDENTIFICATION AND ANTIBACTERIAL ACTIVITY OF ESSENTIAL OIL FROM Zingiber aromaticum Val. RHIZOMES}

\begin{abstract}
Isolation, identification and antibacterial activity of volatile oil from Zingiber aromaticum Val rhizomes have been evaluation. The essential oil was isolated by Stahl distillation method and analyzed by gas chromatography and mass spectrometry (GC-MS). The yield of the volatile oil was $0.6 \%(\mathrm{v} / \mathrm{w})$ and the compounds were determined by comparing their mass spectrum with mass spectrum standart from the Wiley 7. LIB. Twenty seven compounds were identified, the compounds were $\alpha$ - pinene $(0.36 \%), \mathrm{Z}-$ ocimene (2.70\%), Champhen (10.91\%), Sabinene $(0.07 \%), \beta$ - pinene $(0.18 \%), \beta$ - myrcen
\end{abstract}


$(0.29 \%), \mathrm{p}-$ cimene $(0.50 \%), 1,8$ cineole $(2.75 \%), \beta$ - trans ocimene $(0.05 \%)$, alloocimene $(0.18) \%, \gamma$ - terpinene $(0.14 \%), \alpha$ - terpinolene $(27.19 \%)$, champor $(2.71 \%)$, Isobornyl alcohol (1.51\%), Terpinene 4-ol (1.11\%), 3-cyclohexana 1 methanol (0.25\%), 3cyclohexana 1 methanol $(0.25 \%)$, Isobornyl acetate $(0.29 \%)$, Trans caryophilen $(0.47 \%)$, $\alpha$-humulen $(7.53 \%), \alpha$-curcumen $(0.13) \%$, farnesol $(0.11 \%)$, caryophyllene oxyde $(2.07 \%)$, callarene $(0.11) \%$, $\beta$-eudesmol, (0.29\%) patchulana $(3.48 \%)$, Zerumbon $(31.05 \%)$.

The antibacterial activity of the volatile oil from rhizomes of Zingiber aromaticum Val was tested against Pseudomonas aeruginosa, Bacillus cereus and Salmonella typhi using a disc diffusion method with cup-plate technique. The results showed that the volatile oil from Zingiber aromaticum Val rhizomes has antibacterial activity to of all tested bacteria with Minimal Inhibitory Concentration (MIC) were $0.25 \%$ for Pseudomonas aeruginosa, and $0.1 \%$ for Salmonella typhi. Compared with amoxicillin, the antibacterial activity of volatile oil from Zingiber aromaticum Val rhizomes at two tested bacteria was $0.001 \%$ of amoxicillin.

Keyword : Zingiber aromaticum Val, volatile oil, antibacterial activity

\section{PENDAHULUAN}

Lempuyang wangi (Zingiber aromaticum Val.) merupakan tanaman obat yang sering digunakan oleh masyarakat di Jawa dan Sumatera. Rimpang tanaman ini sering digunakan untuk obat asma, merangsang membran mukosa lambung, mengurangi rasa nyeri, pembersih darah, menambah nafsu makan, menurunkan kesuburan pada wanita, pencegah kehamilan, pereda kejang, untuk mengobati penyakit empedu, penyakit kuning, radang sendi, batuk rejan, kolera, anemia, malaria, penyakit syaraf, nyeri perut, mengatasi penyakit yang disebabkan cacing, dan masuk angin. Pada pemakaian luar, digunakan untuk mengatasi rasa nyeri (Sudarsono dkk., 2002).

Lempuyang wangi juga memiliki kandungan flavonoid yang telah diisolasi dan diidentifikasi oleh peneliti terdahulu. Penelitian yang dilakukan oleh Usia dkk. (2005), menunjukkan bahwa dari ekstrak air rimpang lempuyang wangi yang digunakan untuk pengobatan tradisional, telah diisolasi dan diidentifikasi 16 senyawa dan senyawa-senyawa tersebut memiliki aktivitas penghambatan terhadap CYP3A4. Lempuyang wangi juga memiliki khasiat sebagai antibakteri, hal ini terutama disebabkan karena adanya kandungan minyak atsiri yang telah dikenal berfungsi sebagai antibakteri. Minyak atsiri lempuyang wangi dilaporkan memiliki aktivitas sebagai antibakteri, dapat menghambat pertumbuhan Streptococcus alpha secara in vitro, daya antibakteri berbanding lurus dengan konsentrasi. Perasan, infusa, dan minyak atsiri lempuyang wangi mempunyai daya antibakteri terhadap Staphylococcus aureus lebih baik dibanding terhadap Escheriscia coli. Potensi daya antibakteri minyak atsiri lebih besar dari perasan rimpang dan lebih besar dari infusa (Widyowati, 1994).

Rimpang kering lempuyang wangi mengandung sekitar $0,93 \%$ minyak atsiri dengan komposisi $\alpha$-pinena $(7,86 \%)$, kamfena $(31,27 \%), \beta$-pinena $(2,39 \%), \beta$ cis-osimena $(3,41 \%)$, allo-ocimene $(0.08) \%, \alpha$-terpinena $(0,84 \%), 3$-karena $(1,80 \%)$, sineol $(6,36 \%), \quad 4$-karena (1,25\%), $\beta$-linalol (14,16\%), DL-kamfor $(2,92 \%), \quad 4$-metil-1(1-metilelil)-3sikloheksen-1-ol $(2,06 \%)$, isokariofilena $(0,76 \%), \alpha$-kariofilena $(9,49 \%)$, patchulana $(0,67 \%), \alpha$-farnesena $(1,58 \%)$, kariofilena oksida $(3,13 \%)$, dan 
germakron (10,05\%) (Agusta, 2000). Dalam rangka pengembangan pemanfaatan tanaman herba di Indonesia, khususnya rimpang lempuyang wangi yang selama ini belum banyak diteliti, maka perlu dilakukan penelitian guna mengetahui kemampuan minyak atsiri rimpang lempuyang wangi sebagai antibakteri terhadap bakteri patogen terhadap manusia yaitu Pseudomonas aeruginosa dan Salmonella typhi.

\section{METODE PENELITIAN}

\section{Alat dan Bahan}

Bahan yang digunakan dalam penelitian ini adalah : alat destilasi Stahl, Gas Chromatography-Spektrometer Massa, Alat- alat gelas.

Bahan yang digunakan dalam penelitian ini adalah rimpang Zingiber aromaticum Val. diperoleh dari Balai Pengembangan Tanaman Obat (BPTO) Tawangmangu, Karanganyar yang telah dideterminasi di bagian Biologi Farmasi, Fakultas Farmasi Universitas Gadjah Mada, Natrium sulfat anhidrat, aquades, amoksisilin (Merck), nutrient agar (media pertumbuhan bakteri), eter, $\mathrm{n}$ heksana, bakteri $P$. aeuroginosa dan S. typhi.

\section{Prosedur Penelitian}

Penelitian dilakukan dengan menggunakan metode eksperimental di laboratorium. Isolasi minyak atsiri rimpang lempuyang wangi dilakukan dengan metode destilasi Stahl. Identifikasi komponen minyak atsiri dilakukan melalui pendekatan struktur dengan metode spektrometri. Spektrometer yang digunakan merupakan gabungan kromatografi gas dan spektrometer massa (GC-MS). Uji aktivitas antibakteri minyak atsiri dilakukan dengan metode difusi dengan teknik sumuran dan uji banding potensi antibakteri dengan menggunakan pembanding antibiotik amoksisilin.

\section{HASIL DAN PEMBAHASAN}

Minyak Atsiri yang diperoleh dari hasil destilasi Stahl berupa cairan berwarna kuning jernih dan berbau khas dengan kadar 0,6\%. Pengujian aktivitas antibakteri minyak atsiri rimpang lempuyang wangi dilakukan terhadap dua bakteri uji yaitu $P$. aeruginosa dan $S$. typhi dengan metode difusi agar dengan teknik sumuran.

\section{Uji aktivitas antibakteri minyak atsiri rimpang lempuyang wangi}

Pengujian aktivitas antibakteri minyak atsiri rimpang lempuyang wangi dilakukan terhadap dua bakteri uji yaitu $P$. aeruginosa dan $S$. typhi dengan metode difusi agar dengan teknik sumuran. Hasil pengujian diperoleh bahwa minyak atsiri rimpang lempuyang wangi pada konsentrasi 100\%, 75\%, 50\% dan $50 \%$ menunjukkan terbentuknya zona bening disekitar sumuran. Jadi, dapat dikatakan minyak atsiri rimpang lempuyang wangi dapat menghambat pertumbuhan bakteri $P$. aeruginosa dan $S$. typhi. Data aktivitas penghambatan dengan cara mengukur diameter daerah hambat (DDH) disajikan dalam Tabel 1.

Tabel 1. Data aktivitas penghambatan minyak atsiri rimpang lempuyang wangi dengan parameter DDH

\begin{tabular}{|l|l|c|}
\hline $\begin{array}{c}\text { Konsen- } \\
\text { trasi } \\
\text { minyak } \\
\text { atsiri }\end{array}$ & \multicolumn{2}{|c|}{$\begin{array}{r}\text { Diameter Daerah Hambat } \\
(\mathrm{DDH}) \mathrm{mm}\end{array}$} \\
\cline { 2 - 3 } & $P$. aeruginosa & S. typhi \\
\hline $0.75 \%$ & $8.80 \pm 0.25$ & $9.47 \pm 0.07$ \\
\hline $0.5 \%$ & $8.36 \pm 0.13$ & $8.76 \pm 0.25$ \\
\hline $0.25 \%$ & $6.69 \pm 0.31$ & $8.22 \pm 0.25$ \\
\hline $0.1 \%$ & $6.00 \pm 0.00$ & $6.97 \pm 0.22$ \\
\hline $0.075 \%$ & - & $6.00 \pm 0.00$ \\
\hline
\end{tabular}

Tabel 1. (Lanjutan)

\begin{tabular}{|l|l}
\hline Konsen- & Diameter Daerah Hambat
\end{tabular} 


\begin{tabular}{|c|l|l|}
\hline \multirow{2}{*}{$\begin{array}{c}\text { trasi } \\
\text { minyak } \\
\text { atsiri }\end{array}$} & \multicolumn{2}{|c|}{ (DDH) mm } \\
\cline { 2 - 3 } & $P$. aeruginosa & S. typhi \\
\hline $0.05 \%$ & - & $6.00 \pm 0.00$ \\
\hline
\end{tabular}

Keterangan:

Hasil $3 x$ pengujian

Diameter lubang $=6 \mathrm{~mm}$

DDH $=$ Diameter Daerah Hambat (mm)

Hasil pengukuran diameter hambat pada tabel menunjukkan Diameter Daerah Hambat (DDH) minyak atsiri rimpang lempuyang wangi terhadap bakteri $S$. typhi lebih besar daripada $P$. aeruginosa. Hasil uji diatas menunjukkan bahwa minyak atsiri rimpang Zingiber aromaticum Val. menunjukkan penghambatan terhadap bakteri uji. Besarnya daerah hambatan dipengaruhi oleh komposisi dan konsentrasi minyak atsiri serta jenis dan jumlah bakteri (Baydar et al., 2004). Banyaknya komponen kimia yang terkandung dalam minyak atsiri, memungkinkan aktivitas kerja antibakterinya tidak hanya melalui satu cara yang spesifik melainkan ada beberapa cara dan target pada sel bakteri (Carson et al., 2002). Aktivitas kerja gabungan dari beberapa senyawa antibakteri dapat lebih efektif dibandingkan dengan daya kerja masingmasing senyawa (Jawetz dkk., 1982).

\section{Penetapan KHM amoksisilin}

Uji pembanding atau uji terhadap kontrol positif dalam uji antibakteri ini menggunakan antibiotik sintesis yaitu amoksisilin. Pemilihan amoksisilin sebagai pembanding dikarenakan amoksisilin merupakan antibiotik yang memiliki cakupan spektrum penghambatan yang luas sehingga bisa digunakan untuk menghambat bakteri gram positif seperti $B$. cereus dan bakteri gram negatif seperti $P$. aeruginosa dan $S$. typhi.
Kurva log konsentrasi amoksisilin vs DDH untuk bakteri $S$. typhi dapat dilihat pada Gambar 1.

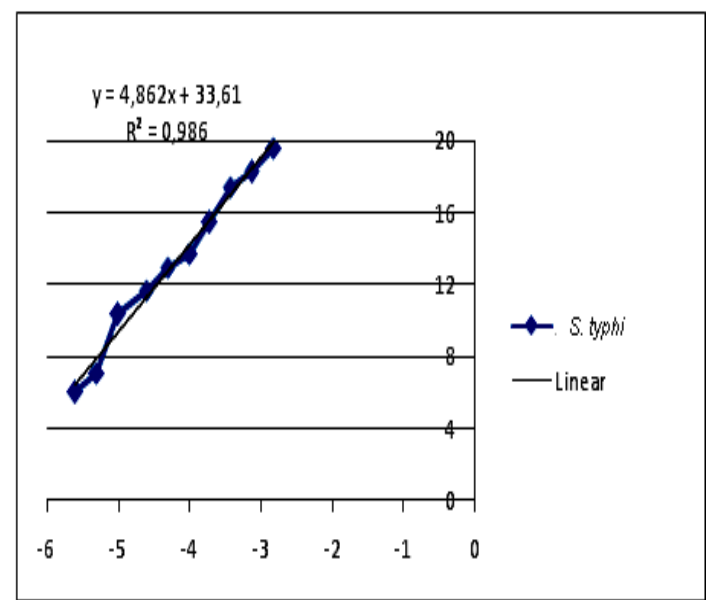

Gambar 1. Kurva log konsentrasi amoksisilin vs DDH terhadap S. typhi

Dari persamaan kurva yang terbentuk, untuk mengetahui potensi antibakterinya, kita masukkan parameter harga DDH dan konsentrasi minyak atsiri terhadap $S$. typhi. Untuk konsentrasi minyak atsiri 0,1\% diperoleh DDH 6,97 $\mathrm{mm}$. Potensi minyak atsiri dibanding amoksisilin

$$
=\frac{3,31810^{-6}}{0,1} \times 100 \%=0,003 \%
$$

Kurva log konsentrasi amoksisilin vs DDH terhadap $P$. aeruginosa terlihat pada Gambar 2.

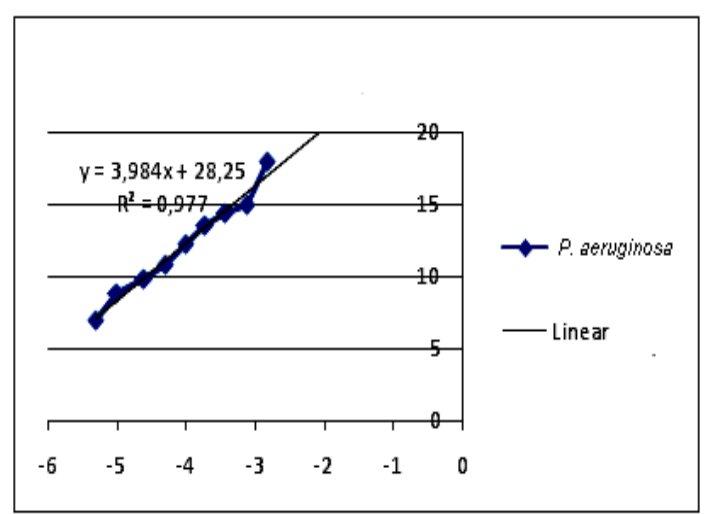

Gambar 2. Kurva log konsentrasi amoksisilin vs DDH terhadap P. aeruginosa

Dari persamaan kurva yang terbentuk, untuk mengetahui potensi 
antibakterinya, kita masukkan parameter harga DDH dan konsentrasi minyak atsiri terhadap $P$. aeruginosa. $=0,002 \%$. Hasil tersebut menunjukkan bahwa minyak atsiri lempuyang wangi berpotensi sebagai antibakteri terhadap S. typhi dan $P$. aeruginosa meskipun potensinya masih jauh lebih kecil dibanding antibiotik Amoksisilin.

\section{Hasil Analisis Kromatografi Gas- Spektrometer Massa}

Hasil kromatogram dari data GCMS pada minyak atsiri rimpang lempuyang wangi menunjukkan terdapat 41 komponen (41 puncak), namun yang teridentifikasi sebanyak 27. Kromatogram GC-MS minyak atsiri daun rimpang lempuyang wangi ditunjukkan oleh Gambar 3.
Analisis kandungan minyak atsiri pada penelitian ini tidak dilakukan dengan cara perbandingan waktu retensi dengan senyawa pembanding, akan tetapi dengan cara melakukan analisis spektra massanya. Analisis spektra massa didasarkan pada nilai Similarity Indeks (SI), base peak (puncak dasar), dan trend pecahan spektra massa. Meskipun dalam kromatogram terdapat 41 puncak tetapi dari hasil analisis spektra massa diperoleh sebanyak 27 senyawa yang memiliki puncak dasar dan pola fragmentasi yang mirip dengan senyawa standar dari Wiley 7 LIB.

Data spektra massa GC-MS dari 24 puncak komponen minyak atsiri rimpang lempuyang wangi disajikan pada Tabel 2.

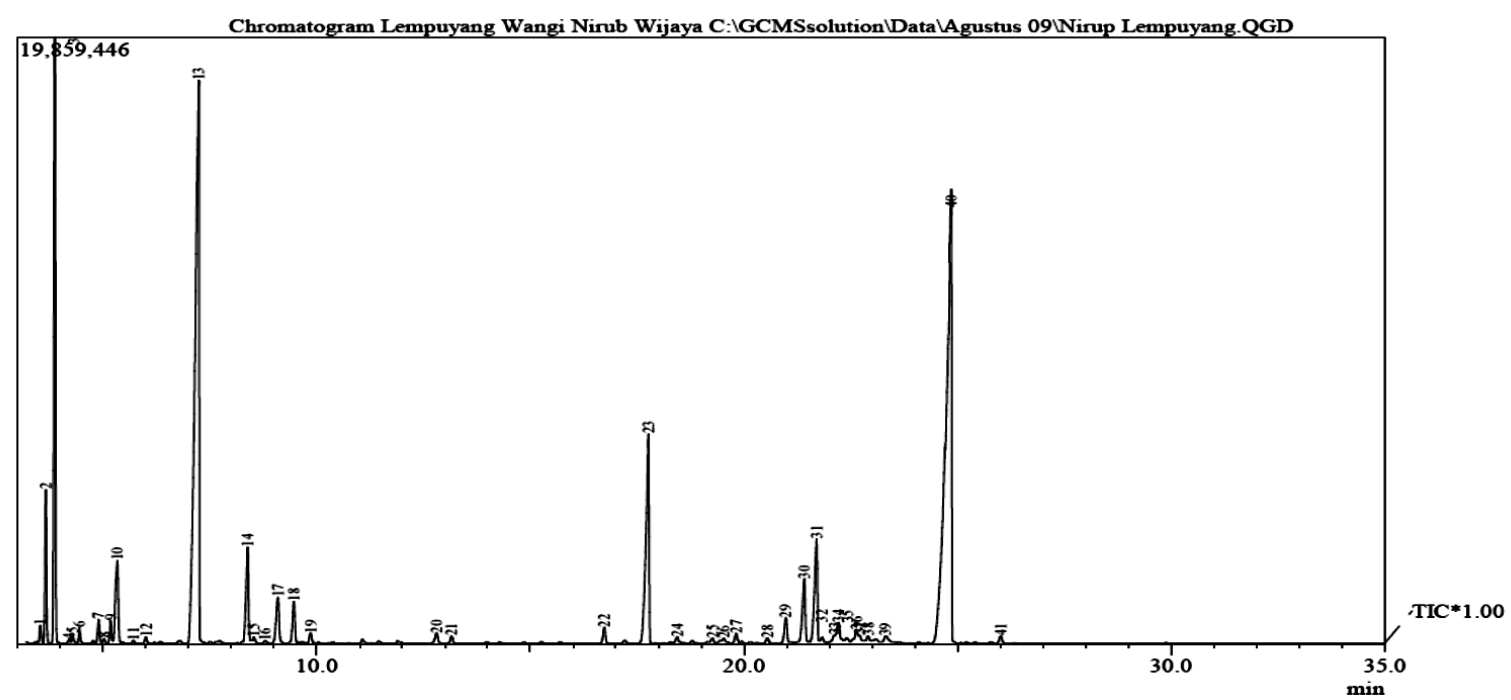

Gambar 3. Kromatogram hasil pemisahan kromatografi gas sampel minyak atsiri rimpang lempuyang wangi

Tabel 2. Komponen utama minyak atsiri rimpang lempuyang wangi

\begin{tabular}{|c|c|c|l|l|r|}
\hline No & $\begin{array}{c}\text { tR } \\
(\mathbf{m e n i t})\end{array}$ & SI & \multicolumn{1}{|c|}{ Fragmen $(\mathbf{m} / \mathbf{z})$} & \multicolumn{1}{|c|}{$\begin{array}{c}\text { Perkiraan } \\
\text { senyawa }\end{array}$} & $\begin{array}{c}\text { Komposisi } \\
(\mathbf{\%})\end{array}$ \\
\hline 1. & 3,53 & 94 & $\begin{array}{l}136,121,105, \mathbf{9 3}(\mathbf{1 0 0} \%), \\
77,67,53,41\end{array}$ & $\alpha$-pinena & 0,36 \\
\hline 2. & 3,66 & 96 & $\begin{array}{l}136,121,105, \mathbf{9 3}(\mathbf{1 0 0}), \\
77,67,53,39\end{array}$ & $(Z)-\beta$-osimen & 2,70 \\
\hline
\end{tabular}


Tabel 2. (Lanjutan)

\begin{tabular}{|c|c|c|c|c|c|}
\hline No & $\begin{array}{c}\mathbf{t R} \\
\text { (menit) }\end{array}$ & SI & Fragmen $(\mathbf{m} / \mathbf{z})$ & $\begin{array}{c}\text { Perkiraan } \\
\text { senyawa }\end{array}$ & $\begin{array}{c}\text { Komposisi } \\
(\%)\end{array}$ \\
\hline 3. & 3,87 & 96 & $\begin{array}{l}\text { 136, 121, 107, } 93(\mathbf{1 0 0 \%}), \\
79,67,53,41\end{array}$ & kamfena & 10,91 \\
\hline 4. & 4,20 & 94 & $\begin{array}{l}\text { 136, 121, 107, } 93(\mathbf{1 0 0 \%}), \\
77,69,53,41\end{array}$ & sabinena & 0,07 \\
\hline 5. & 4,28 & 97 & $\begin{array}{l}\text { 136, 121, 107, } 93(\mathbf{1 0 0 \%}), \\
77,69,53,41\end{array}$ & $\beta$-pinena & 0,18 \\
\hline 6. & 4,45 & 95 & $\begin{array}{l}\text { 136, 121, 107, 93, 79, 69, 53, } \\
\mathbf{4 1 ( 1 0 0 \% )}\end{array}$ & $\beta$-mirsena & 0,29 \\
\hline 7. & 4,89 & 94 & $\begin{array}{l}\text { 136, 121, 105, } 93(\mathbf{1 0 0 \%}) \\
77,67,43,39\end{array}$ & $(Z)$ - $\alpha$-osimen & 0,51 \\
\hline 8. & 5,05 & 89 & $\begin{array}{l}\text { 136, 121, 105, 93, 77, 67, } \\
\mathbf{4 3 ( 1 0 0 \% ) , 4 1}\end{array}$ & allo-osimen & 0,08 \\
\hline 9. & 5,18 & 93 & $\begin{array}{l}\text { 134, 119 (100\%), 103, 91, } \\
77,65,51,39\end{array}$ & $p$-simen & 0,50 \\
\hline 10. & 5,33 & 93 & $\begin{array}{l}\text { 154, 139, 121, 108, 93, 81, } \\
68, \mathbf{4 3}(\mathbf{1 0 0 \% )}, 41\end{array}$ & 1,8-sineol & 2,75 \\
\hline 11. & 5,71 & 93 & $\begin{array}{l}\text { 136, 121, 105, } 93(\mathbf{1 0 0 \%}), \\
79,67,53,41\end{array}$ & $(E)$ - $\beta$-osimen & 0,05 \\
\hline 12. & 6,00 & 96 & $\begin{array}{l}\text { 136, 121, 105, } 93(\mathbf{1 0 0 \%}), \\
77,65,41\end{array}$ & $\gamma$-terpinena & 0,14 \\
\hline 13. & 7,24 & 97 & $\begin{array}{l}\text { 136, 121, 107, 93, 71, 69, } \\
\mathbf{4 1 ( 1 0 0 \% )}\end{array}$ & $\alpha$-terpinolen & 27,19 \\
\hline 14. & 8,38 & 96 & $\begin{array}{l}\text { 152, 137, 108, 95, 81, 69, 55, } \\
\mathbf{4 1 ( 1 0 0 \% )}\end{array}$ & kamfor & 2,71 \\
\hline 15. & 9,09 & 89 & $\begin{array}{l}\text { 140, 139, 121, 108, 95 } \\
(\mathbf{1 0 0 \% )}, 77,67,43,41\end{array}$ & 1-borneol & 1,51 \\
\hline 16. & 9,46 & 96 & 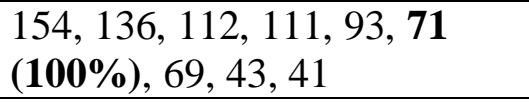 & terpinen-4-ol & 1,11 \\
\hline 17. & 9,86 & 97 & $\begin{array}{l}136,121,107,93,81 \\
\mathbf{5 9}(\mathbf{1 0 0 \%}), 43,41\end{array}$ & $\begin{array}{l}\text { 3- } \\
\text { sikloheksena- } \\
\text { 1-methanol } \\
\end{array}$ & 0,25 \\
\hline 18. & 12,81 & 96 & $\begin{array}{l}\text { 154, 136, 121, 108, 95, 67, } 43 \\
(\mathbf{1 0 0 \% ) , 4 1}\end{array}$ & $\begin{array}{l}\text { isobornil } \\
\text { asetat }\end{array}$ & 0,29 \\
\hline 19. & 26,73 & 96 & $\begin{array}{l}\text { 189, 161, 147, 133, 120, 105, } \\
91,79,69,53, \mathbf{4 1}(\mathbf{1 0 0 \%})\end{array}$ & $\begin{array}{l}\text { trans- } \\
\text { kariofilen }\end{array}$ & 0,42 \\
\hline 20. & 17,77 & 97 & $\begin{array}{l}\text { 204, 161, 147, 136, 121, 107, } \\
\mathbf{9 3}(\mathbf{1 0 0 \% )}, 80,67,53,41\end{array}$ & $\alpha$-humulen & 7,53 \\
\hline 21. & 18,44 & 87 & $\begin{array}{l}202,159,145,132,119,105, \\
91,77,69,55, \mathbf{4 1}(\mathbf{1 0 0 \%})\end{array}$ & $\alpha$-kurkumen & 0,13 \\
\hline 22. & 19,27 & 88 & $\begin{array}{l}204,189,176,161,147,133, \\
119,105,91,79,67,43, \mathbf{4 1} \\
(\mathbf{1 0 0 \% )}\end{array}$ & kalarena & 0,10 \\
\hline 23. & 19,82 & 88 & $\begin{array}{l}\text { 191, 177, 163, 150, 135, 122, } \\
\text { 107, 93, 79, 67, 55, 41 } \\
(\mathbf{1 0 0 \% )}\end{array}$ & patchulana & 0,25 \\
\hline
\end{tabular}


Tabel 2. (Lanjutan)

\begin{tabular}{|c|c|c|l|l|r|}
\hline No & $\begin{array}{c}\text { tR } \\
(\mathbf{m e n i t )}\end{array}$ & SI & \multicolumn{1}{|c|}{ Fragmen $(\mathbf{m} / \mathbf{z})$} & \multicolumn{1}{|c|}{$\begin{array}{c}\text { Perkiraan } \\
\text { senyawa }\end{array}$} & \multicolumn{1}{|c|}{$\begin{array}{c}\text { Komposisi } \\
(\mathbf{\%})\end{array}$} \\
\hline 24. & 20,55 & 96 & $\begin{array}{l}161,136,121,107,93,71, \\
69,43, \mathbf{4 1}(\mathbf{1 0 0})\end{array}$ & farnesol & 0,11 \\
\hline 25. & 21,42 & 86 & $\begin{array}{l}161,149,135,121,109,91, \\
79,69, \mathbf{4 1}(\mathbf{1 0 0} \%)\end{array}$ & $\begin{array}{l}(-) \text {-kariofilen } \\
\text { oksida }\end{array}$ & 2,07 \\
\hline 26. & 22,63 & 86 & $\begin{array}{l}189,164,149,135,122,108, \\
91,79, \mathbf{5 9}(\mathbf{1 0 0} \%), 41\end{array}$ & $\beta$-eudesmol & 0,29 \\
\hline 27. & 24,84 & 89 & $\begin{array}{l}218,203,189,175,163,149, \\
135,121,107,96,79,67,53, \\
\mathbf{4 1}(\mathbf{1 0 0 \%})\end{array}$ & zerumbon & 31,05 \\
& & & \multicolumn{2}{|c|}{ Total senyawa teridentifikasi } & $93,55 \%$ \\
\hline
\end{tabular}

\section{KESIMPULAN}

Minyak atsiri lempuyang wangi hasil isolasi dengan metode destilasi Stahl menghasilkan rendemen sebesar $0,6 \%$ dan mempunyai aktivitas antibakteri terhadap $P$. aeruginosa dan $S$. typhi. Hasil identifikasi dengan GC-MS didapat 27 komponen utama. Uji banding potensi antibakteri minyak atsiri lempuyang wangi dan antibiotik amoksisilin terhadap bakteri $S$. typhi dan $P$. aeruginosa sebesar didapatkan nilai sebesar $0,001 \%$.

\section{DAFTAR PUSTAKA}

Agusta, A., 2000, Minyak Atsiri Tumbuhan Tropika Indonesia, 98, Penerbit ITB, Bandung.

Baydar, H., Sagdic, O., Ozkan, G. and Karadogan, T., 2004. Antibacterial activity and composition of essential oils from Origanum, Thymbra and Satureja species with commercial importance in Turkey. Food Con, 15: 169-172.

Carson, C.F. Mee, B.J., Riley, T.V., 2002. Mechanism of action of Melaleuca alternifolia (tea tree) oil on Staphylococcus aureus determined by time-kill, lysis, leakage and salt tolerance assays and electron microscopy. Antimicrobial Agents and Chemotherapy, 46(6): 1914-1920.

Jawetz, E., Melnick, G.E and Adelberg, C.A., 2001., Mikrobiologi Kedokteran, Edisi I, diterjemahkan oleh penerjemah Bagian Mikrobiologi Fakultas Kedokteran Universitas Airlangga, Salemba Medika, Surabaya

Sudarsono, Gunawan, D., Wahyuono, S., 2002, Tumbuhan Obat II : Hasil Penelitian, Sifat- sifat dan Penggunaan, 186, Pusat Studi Obat Tradisional UGM, Yogyakarta.

Usia,T.,Watabe., Kadota, S., dan Tezuka,Y., 2005, MechanismBased Inhibition of CYP3A4 by Constituen of Zingiber aromaticum, Biol. Pharm.Bull. 28 (3): 495-499.

Widyowati, R.,1994, Daya Antibakteri Rimpang Lempuyang Wangi (Zingiber aromaticum Val. ) terhadap Staphylococcus aureus dan Escheriscia coli Koleksi Laboratorium Mikrobiologi UGM, Fakultas Kedokteran UGM, Yogyakarta. 